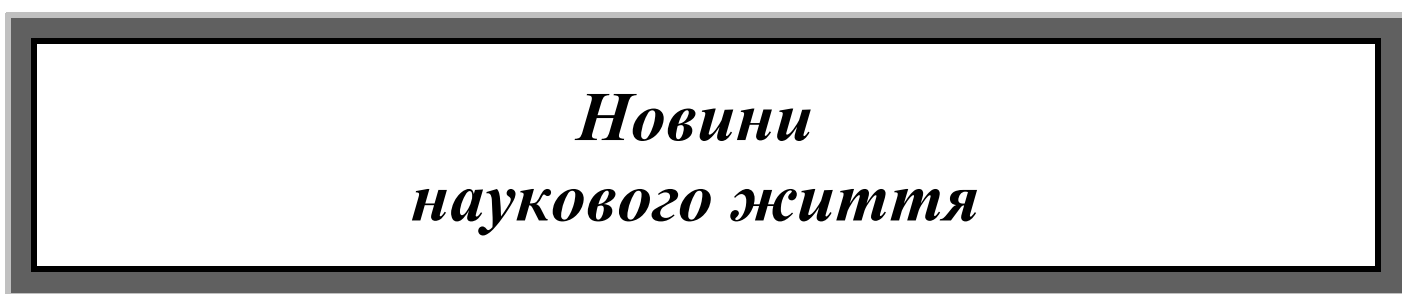

DOI https://doi.org/10.32782/2409-4544/2019-2/26

\title{
Всеукраїнська наукова конференція, присвячена 100-річчю від дня народження професора В. С. Кульчицького
}

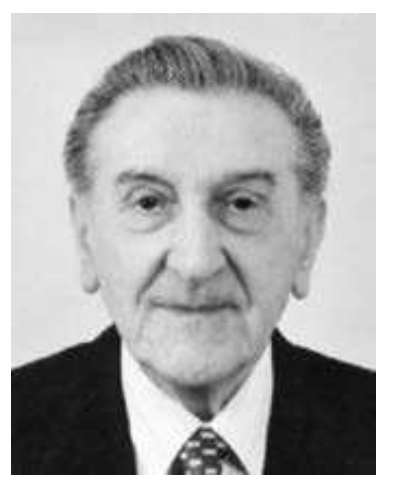

15 листопада 2019 р. $з$ ініціативи кафедри історії держави, права та політико-правових учень на юридичному факультеті Львівського національного університету імені Івана Франка відбулася Всеукраїнська наукова конференція на тему: «Актуальні проблеми історії держави i права України та наукова спадщина професора Володимира Семеновича Кульчицького», присвячена 100-річчю від Дня народження.

У роботі конференції взяли участь понад 50 учасників 3 провідних вузів України. 3 них 18 докторів наук і професорів, 3 академіки НАПрН України, 1 член-кореспондент НАПрН України, 26 кандидатів наук і доцентів, 2 асистенти, 4 аспіранти.

Відкрив роботу конференції Ігор Йосипович Бойко, доктор юридичних наук, професор, завідувач кафедри історії держави, права та політико-правових учень Львівського національного університету імені Івана Франка, який наголосив про те, що ця конференція присвячена 100річчю від дня народження талановитого вченого в галузі історії держави та права, видатного представника української академічної юридичної науки другої половини XX - початку XXI ст., доктора юридичних наук, професора, Члена-кореспонденту Національної академії правових наук України, заслуженого юриста України, заслуженого професора Львівського національного університету імені Івана Франка, засновника Львівської історико-правової наукової школи Володимира Семеновича Кульчицького, якому 28 грудня 2019 р. виповнилось би 100 років від Дня народження.

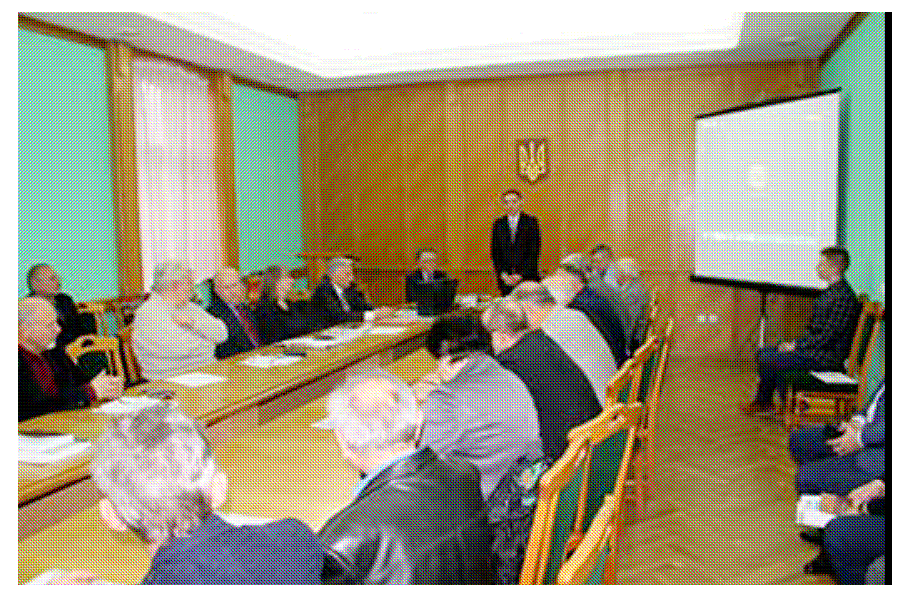


Народився В. С. Кульчицький 28 грудня 1919 р. в селянській сім’ї у селі Кульчиці на Самбірщині, цьому славному селі, що дало Україні гетьманів Петра Конашевича-Сагайдачного, Івана Сулиму і Марка Жмайла, знаменитого Юрія Кульчицького, який доклався до порятунку Відня від турків та започаткував у Свропі звичай пити каву. До речі, український шляхетський рід Кульчицьких - це прямі нащадки короля Данила Галицького, гетьманів Петра Сагайдачного, Марка Жмайла, героя оборони Відня 1683 р. та засновника першої у Свропі кав'ярні Юрія Кульчицького, мати Івана Франка - Марія Кульчицька і цей перелік можна продовжувати. В рідному селі Володимир закінчив початкову школу, згодом вступив до Самбірської гімназії, яку свого часу (у другій половині XIX ст.) закінчило кілька відомих українських громадськополітичних діячів. 3-поміж них - Андрій Чайковський, один з найпопулярніших письменників історичних романів, випускник юридичного факультету Львівського університету (1883р.), повітовий комісар Західно-Української Народної Республіки у Самбірському повіті.

Після закінчення гімназії у 1939 р. вступив на перший курс юридичного факультету Львівського університету, що тоді називався університетом імені короля Яна Казимира ще у складі Польщі. Проте німецько-радянська війна перервала навчання на факультеті.

Після звільнення Галичини від нацистських загарбників, 18 серпня 1944 p., В. С. Кульчицького мобілізували до лав Радянської армії. Наприкінці вересня цього ж року він був тяжко поранений і демобілізований, отримавши статус інваліда Великої Вітчизняної війни. Бойові та професійні заслуги В.С. Кульчицького відзначені орденом Вітчизняної війни I ступеня, 11 медалями і нагрудним знаком Державного комітету СРСР 3 народної освіти «За відмінні успіхи в праці».

Після війни Володимир Кульчицький продовжив навчання на III курсі денної форми навчання юридичного факультету Львівського державного університету, деканом якого тоді ще був польський професор, історик права П. Домбковський. і закінчив його 1948 р. У той час прийом на денне навчання не перевищував 40-50 студентів. За перші післявоєнні 5 років (19451949 рр.) було підготовлено лише 205 випускників юридичного факультету, в тому числі В. С. Кульчицького. У 1948 р. він вступив до аспірантури по кафедрі історії та теорії держави та права Львівського державного університету, завідувачем якої був професор П. О. Недбайло. Значну увагу Володимир Семенович зосереджував на дослідженні суспільно-політичного ладу i права на землях Східної Галичини під владою Австрії та Австро-Угорщини. Керував написанням кандидатської дисертації В. С. Кульчицького професор П. Домбковський.

У 1951 р. закінчив навчання в аспірантурі та був зарахований викладачем, згодом старшим викладачем на цій самій кафедрі.

В. С. Кульчицький 19 квітня 1954 р. успішно захистив дисертацію на здобуття наукового ступеня кандидата юридичних наук на тему: «Галицький сейм в системі колоніального апарату Австро-Угорщини». Захист дисертації відбувся на юридичному факультеті Московського університету імені М. В. Ломоносова. Рішенням Вченої ради цього університету Володимирові Семеновичу Кульчицькому присуджено науковий ступінь кандидата юридичних наук. Рішенням Вищої атестаційної комісії В. С. Кульчицькому 4 лютого 1956 р. присвоєно вчене звання доцента кафедри історії та теорії держави і права. 31954 до 1957 рр. його обирали народним засідателем народного суду 3-ї дільниці колишнього Ленінського району м. Львова.

Як глибокий дослідник історії держави і права, В. С. Кульчицький ретельно вивчав різні архіви, щоб висвітлити історію правового становища західноукраїнських земель, зокрема в період XIX - початку XX ст. і на основі цього опублікував статті, наукові розвідки, матеріали конференцій в наукових виданнях України, Москви, Сревана, а також за кордоном ( у Польщі, зокрема, в «Українському календарі», що тоді там видавався). Тісна наукова співпраця у нього склалася, зокрема, з професором Среванського державного університету А. Г. Сукіасяном.

Плідно працював В.С. Кульчицький i над докторською дисертацією. Науковим консультантом у нього була відомий історик права, професор юридичного факультету Московського університету Ксенія (Оксана) Олександрівна Софроненко (сама родом з України), яку адміністрація юридичного факультету Львівського університету іноді запрошувала головою державної екзаменаційної комісії та для читання лекцій студентам. У 1970 р. він захистив дисертацію на здобуття наукового ступеня доктора юридичних наук «Політичний апарат колоніального управління Східною Галичиною (друга половина XIX - початок XX ст.)». Захист 
відбувся у Києві в Інституті держави та права Академії наук УРСР, директором якого був академік, професор Б. М. Бабій. Обсяг дисертації тоді не обмежувався, і дисертація В. С. Кульчицького складалася 3 двох томів, обсягом близько 400 сторінок кожен. Рішенням Вищої атестаційної комісії від 9 квітня 1971 р. В. С. Кульчицькому присуджено науковий ступінь доктора юридичних наук, а 9 лютого 1973 р. присвоєно вчене звання професора кафедри історії та теорії держави і права. Тоді вже, згідно з новим навчальним планом юридичного факультету, крім курсу історія держави та права Союзу РСР, уведено аналогічний курс з Української РСР. Його також спочатку читав один В.С. Кульчицький, згодом ще інші викладачі (доц. Настюк М. І., асист. Галичин В. П.).

Учений добре володів кількома мовами (крім рідної української, ще російською, польською, німецькою), що дозволило йому хоч у деякій мірі користуватися доступними іноземними першоджерелами та науковою літературою. Пишемо - «у деякій мірі», бо в радянські часи більшість іноземних джерел, літератури були засекречені, знаходились у так званих «спецфондах», доступ до яких був вкрай обмежений. Тим не менше професор переважно досліджував актуальні проблеми 3 історії держави та права західноукраїнських земель у різні періоди їхнього розвитку, зокрема, в часи австрійського та польського панування, а також у різні періоди становлення української державності. Він і далі активно займався проблемами українсько-вірменських політично-правових відносин, державно-правового розвитку сусідніх Молдавії, Білорусії та ін., виступав автором і співавтором навчальних посібників і підручників (зокрема, ще в «радянські» часи співавтором фундаментального підручника «Истории государства и права СССР», відп. ред., проф. К. О. Софроненко. - М., 1967) і ін.

Незважаючи на існуючу в радянські часи, заідеологізованість науки i освіти, В. С. Кульчицький зумів при читанні курсів, особливо з історії держави та права Української PCP, знаходити якісь шпаринки, якісь моменти і факти, щоб виховувати у студентів почуття патріотизму, національної гідності, прищепити їм любов до рідної мови, до українських традицій, ознайомити студентів юридичного факультету 3 такими видатними пам'ятками українського права, як «Права, за якими судиться малоросійський народ», «Екстракт малоросійських прав», «Зібрання малоросійських прав», «Суд $\mathrm{i}$ розправа в правах малоросійських» та ін. До того ж, читав він лекції і проводив семінарські заняття завжди українською мовою. Підкреслюємо цей факт, бо в часи генерального секретарства у ЦК КПРС Л. Брежнєва, Ю. Андропова чи К. Черненка юридичний факультет Львівського університету потрохи, але невпинно русифікувався, низка предметів читалися російською мовою (причому не тільки російськомовними викладачами, але й деякі місцеві викладачі теж переходили на російську мову викладання - щоб їх розуміли, як тоді це обгрунтовувалось, студенти з інших союзних республік, які навчались на юридичному факультеті (ïx, щоправда налічувалось по 3-4 особи на курсі).

Високий науковий авторитет і міжнародне визнання дали змогу В. С. Кульчицькому підтримувати широкі наукові контакти з вченими багатьох країн. Професор В. С. Кульчицький один 3 перших українських учених-правознавців досліджував історію правового статусу вірменських громад в Україні. Він був одним 3 ініціаторів i організаторів трьох наукових конференцій, присвячених історичним зв' язкам і дружбі українського і вірменського народів, які відбувалися в Єревані (1959р.), Львові-Києві (1964р.), Сревані (1971р.). Матеріали конференцій було опубліковано в наукових збірниках «Исторические связи и дружба украинского и армянского народов». Окрім цього, В. С. Кульчицький вивчав зв'язки українського 3 польським, молдовським, білоруським, російським, угорським, австрійським, румунським та іншими народами.

По-справжньому розквітнув талант професора $\quad$ В.С. Кульчицького як науковця та педагога після проголошення незалежної Української держави, яку він вітав від чистого серця. Це була довгоочікувана мрія вченого. Саме професор Кульчицький В. С. після проголошення України незалежною державою став автором перших в Україні об' єктивних підручників з історії держави і права України, на яких виховувалось не одне покоління сучасних правників, патріотів нашої держави. Схема і періодизація, методологічні підходи викладання української історії права і держави, закладені Володимиром Семеновичем Кульчицьким, стали основою для викладання 
навчального курсу «Історії держави і права України», якою послуговуються в усіх юридичних навчальних закладах України і донині.

Найбільшим науковим досягнення професора В. С. Кульчицького було визнання всією українською науковою громадськістю здобутків Львівської історико-правової школи, яку він очолював. Саме під керівництвом професора В. С. Кульчицького історико-правова школа почала свій активний розвиток - проводились цікаві дослідження з історії українського права, яким професор присвятив усе своє життя в Університеті. При ньому остаточно сформувалася нова наукова школа саме історії українського права, основоположником якої власне й став професор В. С. Кульчицький.

У новітній період незалежності України в рамках наукової історико-правової школи Львівського університету імені Івана Франка 3 ініціативи професора В. С. Кульчицького розроблено концепції етапів розвитку української держави і права, походження української державності та права, проводиться дослідження основних галузей та інститутів українського права в їхньому історичному розвитку, аналізуються причини здійснення і сутність кодифікацій українського права упродовж історичного розвитку.

Вагомий і багатогранний внесок професора В. С. Кульчицького у розвиток української історико-правової науки відзначено обранням його у 1992 р. членом-кореспондентом Академії правових наук України; у липні 1999 р. за особистий внесок у розвиток дружніх взаємин між народами та зміцнення міжнародного авторитету України йому присвоєно почесне звання «Народний посол України». У жовтні цього ж року він удостоєний Почесної відзнаки лауреата Всеукраїнського конкурсу на краще професійне досягнення «Юрист року» в номінації наукового співробітника за підсумками 1999 р.

У грудні 1999 р. В. С. Кульчицькому Указом Президента України присвоєно почесне звання «Заслужений юрист України», а 10 жовтня 2001 р. Вчена рада Львівського університету присвоїла йому почесне звання «Заслуженого професора Львівського національного університету імені Івана Франка» - за особливі заслуги у розвитку науки і освіти, підготовку наукових кадрів вищої кваліфікації, довголітню науково-педагогічну та громадську діяльність в університеті. У 2006 р. його нагороджено ювілейною медаллю університету з нагоди 150 - річчя від дня народження Івана Франка.

Надзвичайно всебічний є науковий доробок професора Володимира Кульчицького. Він автор чи співавтор біля 500 наукових і науково-популярних праць, зокрема 20 колективних монографій, 20 навчальних посібників, 8 вузівських підручників, кількох сотень статей та матеріалів, понад 30 навчально-методичних розробок. $\mathrm{y}$ своїх працях професор Кульчицький В. С. досліджував гострі політичні та маловідомі державно-правові проблеми 3 історії становлення й розвитку Української державності у різні періоди іiі існування, інші вагомі і актуальні питання з історії держави, права, політичних систем та ін.

Кульчицький В. С. - співавтор «Юридичної енциклопедії», виданої у шеститомному варіанті у Києві в 1998-2004 рр., член Вченої ради на юридичному факультеті Львівського національного університету імені Івана Франка.

Професор В. С. Кульчицький був членом Наукової ради юридичного журналу «Право України» (м. Київ), членом спеціалізованої вченої ради Д 35.05 .03 у Львівському національному університеті імені Івана Франка. Упродовж десятків років керував він й студентським науковим гуртком, члени якого отримували дипломи й інші відзнаки на всеукраїнських конкурсах, олімпіадах тощо.

Своїми знаннями й досвідом професор В. С. Кульчицький щедро ділився 3 молоддю. Упродовж багатьох років він читав курси та спецкурси, керував науковою роботою магістрів, аспірантів та докторантів, Як науковий керівник або консультант Володимир Семенович безпосередньо сприяв підготовці i захисту докторських дисертацій О. Д. Святоцького, М. М. Кобилецького, І. Й. Бойка, а також кандидатських дисертацій О. І. Мінаєва, Т. В. Фецича, О. Д. Святоцького, М. В. Кравчука, І. Г. Біласа, Я. М. Пігача, Л. Т. Присташ, І. С. Лісної, М. М. Кобилецького, І. Й. Бойка, І. М. Паньонка, О. І. Мікули, І. Ю. Настасяк, О. М. Юхимюк, Я. І. Хомяка, О. О. Сидорчука, О. Я. Паславської, Н. Ю. Панича, В.О. Святоцької, Ю. В. Сеньків. Чимало цих здобувачів під час навчання на юридичному факультеті Львівського університету працювали у студентському науковому гуртку 3 історії держави та права України, яким упродовж 60 років опікувався В. С. Кульчицький. 
В. С. Кульчицький помер 23 липня 2009 р. і був похований у Львові на Личаківському кладовищі.

Володимир Семенович Кульчицький залишив значну теоретичну спадщину і плеяду підготовлених ним учнів - докторів і кандидатів юридичних наук, а також світлу пам'ять про себе. Він був, $є$ і буде прикладом порядності, фаховості, патріотизму та людяності. Світла пам'ять про видатного вченого та вчителя назавжди збережеться у наших серцях.

3 вітальним словом на адресу гостей та учасників конференції виступив ректор Львівського національного університету імені Івана Франка - член-кореспондент Національної академії наук України, доктор філософських наук, професор Володимир Петрович Мельник, який зазначив про те, що Володимир Кульчицький належить до видатних постатей в юридичній науці та у громадсько-політичному житті України. Його наукова спадщина - невід'ємна складова української історико-правової науки і культури. Вона потребує сучасного вивчення, а висловлені ним ідеї - втілення в життя й подальшого розвитку. В. С. Кульчицький був не лише вченимправознавцем України, який написав понад 500 наукових праць. Він був великим гуманістом, патріотом рідної землі. Його ім'я вписане золотими літерами в історію української юриспруденції.

Володимир Семенович Кульчицький відноситься до тієї категорії вчених правознавців, які своїми науковими працями закладали основу української історико-правової науки. Людина наполегливої праці та непересічного духу талановитого дослідника, вихований як вчений на кращих традиціях академічної історико-правової школи Львівського університету, він фактично став фундатором iï у Франковому університеті після проголошення державної незалежності України у 1991 р. Відновлена ним і стараннями його учнів, ця школа стала загальновизнаною в Україні та за ії межами, вона успішно продовжує творити і сучасну історико-правову науку.

3 вітальним словом до гостей та учасників конференції звернувся академік Національної академії правових наук України, доктор юридичних наук, професор, завідувач кафедри кримінального процесу та криміналістики, довголітній декан юридичного факультету Львівського національного університету імені Івана Франка Василь Тимофійович Нор, який також наголосив про те, що В. Кульчицький був талановитим педагогом вищої професійної школи. Його ім'я увійшло до золотого фонду не лише юридичного факультету Львівського національного університету імені Івана Франка, а й усієї української юридичної науки. Володимир Семенович був геніальним науковцем і водночас скромною, приємною, чуйною та доброзичливою людиною. Він був вченим з енциклопедичними знаннями, читав цікаві лекції студентам з курсу Історії держави та права України. Володимир Семенови завжди ділився своїм життєвим i педагогічним досвідом, енциклопедичними знаннями, допомагав в добрих починаннях, давав мудрі поради своїм учням. Професор В.С. Кульчицький був оптимістом, патріотом України. Своїми глибокими за змістом лекціями та семінарськими заняттями, уважним ставленням до студентів, високою загальною й професійною культурою він здобув вдячність $\mathrm{i}$ глибоку пошану колег та багатьох поколінь випускників Львівської правничої школи.

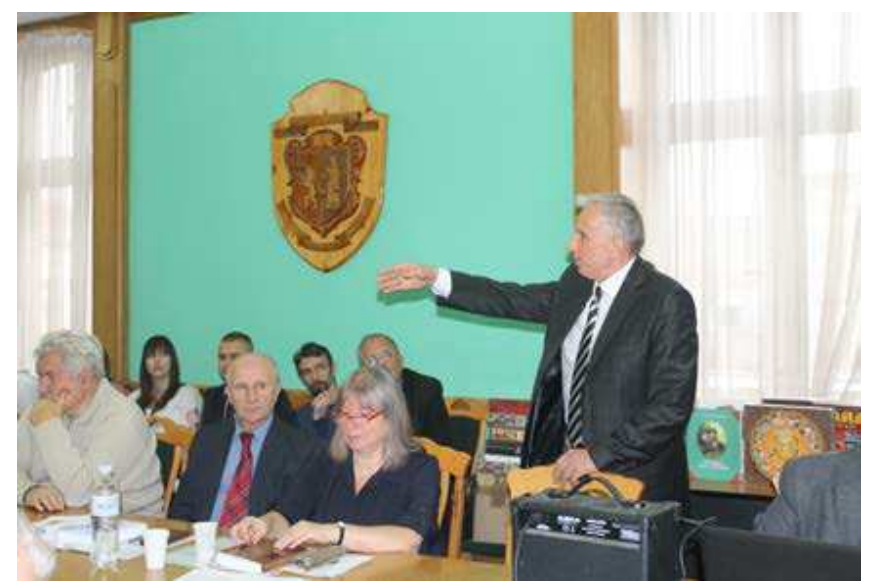

3 словом про Вчителя і доповіддю виступив Олександр Дмитрович Святоцький, доктор юридичних наук, професор, академік НАПрН України, заслужений юрист України, 
головний редактор Юридичного журналу «Право України», який передав привітання на адресу учасників конференції від першого заступника Голови Верховної Ради України, доктора юридичних наук, професора, Члена-кореспондента національної академії правових наук України Руслана Олексійовича Стефанчука. Академік О.Д. Святоцький зазначив про те, що принциповість і порядність, широка ерудованість та відданість науці, сумлінне ставлення до виконання своїх громадських і службових обов'язків, душевна теплота й чуйність здобули Володимирові Семеновичу Кульчицькому високий авторитет і глибоку повагу колег, студентів та керівного складу Львівського національного університету імені Івана Франка, де вчений безперервно працював понад 60 років. Жоден студент, доцент, професор, котрі зверталися до Володимира Семеновича Кульчицького за порадою не залишалися поза його увагою, завжди отримували належні консультації чи рекомендації. Олександр Дмитрович грунтовно проаналізував витоки, етапи становлення та розвиток української державності.

Під час конференції з доповідями виступили Ігор Борисович Усенко, кандидат юридичних наук, професор, завідувач відділу історико-правових досліджень Інституту держави i права імені В. М. Корецького НАН України, заслужений юрист України, лауреат Державної премії України в галузі науки і техніки, Микола Мар'янович Кобилецький, доктор юридичних наук, професор, завідувач кафедри адміністративного та фінансового права Львівського національного університету імені Івана Франка, Світлана Григорівна Ковальова, кандидат юридичних наук, доцент кафедри історії і теорії держави і права Чорноморського національного університету імені Петра Могили, Тарас Григорович Андрусяк, кандидат юридичних наук, доцент кафедри історії держави, права та політико-правових учень Львівського національного університету імені Івана Франка, Юдита Дворас-Кулік доктор філософії, асистент кафедри історії держави і права факультету права, права канонічного і адміністративного Інституту правничих дисциплін Люблінського католицького університету імені Іоанна Павла II (м. Люблін, Республіка Польща), Микола Володимирович Кравчук, кандидат юридичних наук, доцент, доктор права Українського вільного університету, заслужений юрист України, завідувач кафедри теорії та історії держави і права Тернопільського національного економічного університету, Анна Совіковська, доктор філософії, асистент кафедри церковного, публічного i конституційного права факультету права, права канонічного i адміністрації Інституту канонічного права Люблінського католицького університету імені Іоанна Павла II (м. Люблін, Республіка Польща, Олег Антонович Вівчаренко, доктор юридичних наук, професор кафедри трудового, екологічного та аграрного права, заступник директора Навчально-наукового Юридичного інституту Прикарпатського національного університету імені Василя Стефаника, заслужений юрист України, Ельдар Серверович Ванісв, кандидат юридичних наук, АР Крим та ін.

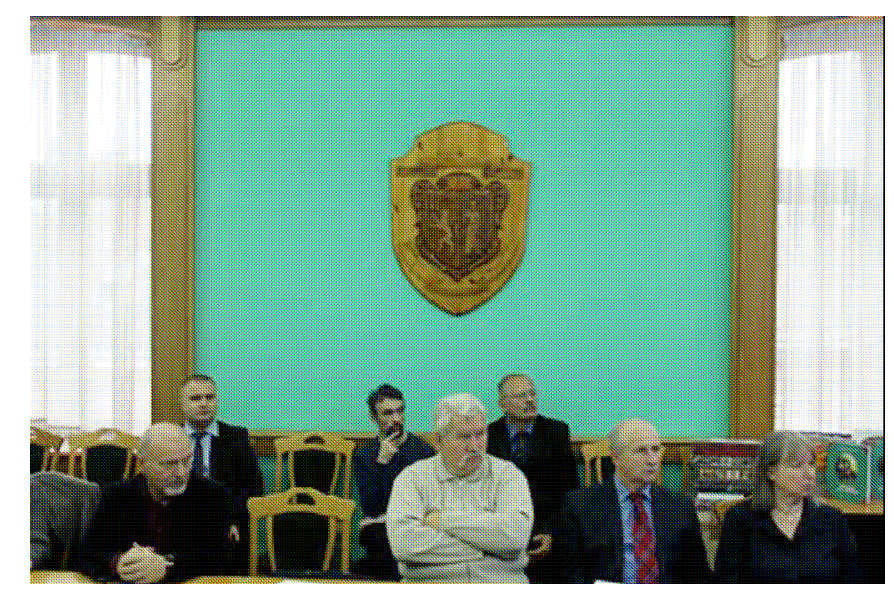

Під час конференції панувала академічна атмосфера: ставилися запитання, неодноразово виникали дискусії, було переглянуто двадцяти хвилинний документальний фільм «За Україну, за іiі волю», а також вшановано хвилиною мовчання полеглих борців за волю України. 


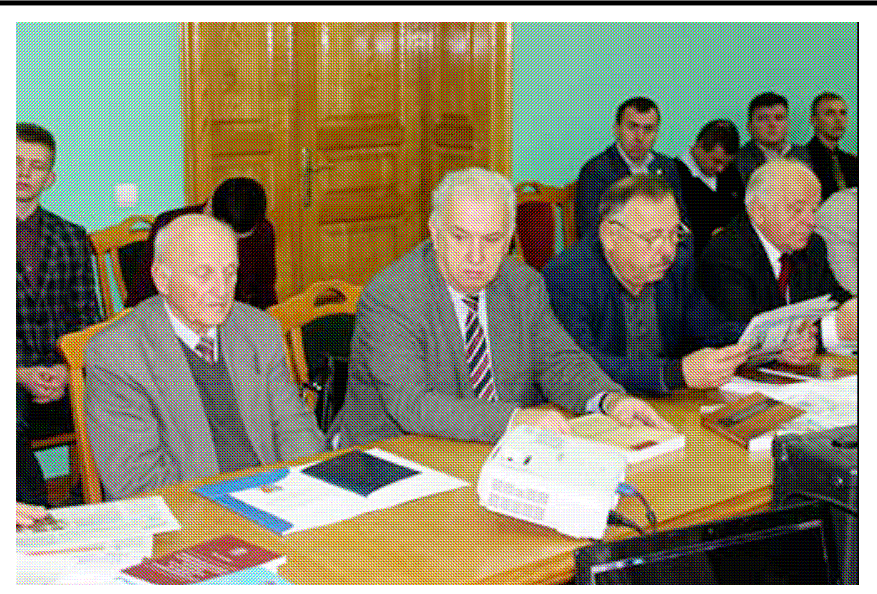

Конференція завершилася підбиттям підсумків роботи. Учасники конференції констатували, що Володимир Семенович Кульчицький залишив по собі світлу пам'ять у серцях широкого загалу науковців, колег та вдячних учнів. 100-річний ювілей Вченого став доброю нагодою для того, щоб ще раз привернути увагу до багатої наукової спадщини правознавця, яка $€$ невід'ємною складовою золотого фонду української історико-правової науки і культури. Вона потребує вивчення, врахування та подальшого розвитку.

Саме таку мету і має ця конференція і Ювілейний збірник наукових праць на пошану професора Володимира Семеновича Кульчицького з нагоди 100 річчя від Дня народження, підготовлений на кафедрі історії держави, права та політико-правових учень юридичного факультету Львівського національного університету імені Івана Франка. У ньому висвітлено етапи життєвого та творчого шляху видатного вченого, педагога і вчителя, професора В. С. Кульчицького, його наукова спадщина, а також актуальні проблеми історії держави і права України. Сучасне покоління студентів правників повинно знати про тих, хто своєю наполегливою і жертовною працею закладав фундамент української історико-правової науки.

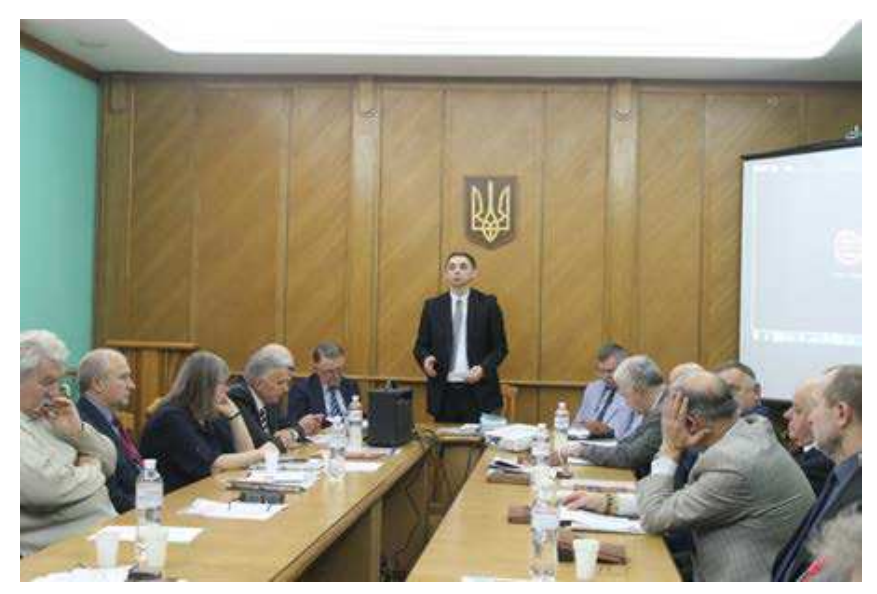

Бойко I. Й., доктор юридичних наук, професор, завідувач кафедри історії держави, права та політико-правових учень Львівського начіонального університету імені Івана Франка 